\author{
UNIVERSIDADE DE SÃO PAULO \\ FACULDADE DE ODONTOLOGIA DE BAURU
}

VICTOR MOSQUIM

Structural, chemical and optical characterizations of an experimental $\mathrm{SiO}_{2}-\mathrm{Y}$-TZP ceramic produced by the uniaxial/isostatic pressing technique

Caracterizações estrutural, química e óptica de uma cerâmica experimental de $\mathrm{SiO}_{2}$-Y-TZP produzida pela técnica de prensagem uniaxial/isostática 

VICTOR MOSQUIM

Structural, chemical and optical characterizations of an experimental $\mathrm{SiO}_{2}-\mathrm{Y}-\mathrm{TZP}$ ceramic produced by the uniaxial/isostatic pressing technique

\begin{abstract}
Caracterizações estrutural, química e óptica de uma cerâmica experimental de $\mathrm{SiO}_{2}-\mathrm{Y}$-TZP produzida pela técnica de prensagem uniaxial/isostática
\end{abstract}

Dissertação constituída por artigo apresentada a Faculdade de Odontologia de Bauru da Universidade de São Paulo para obtenção do título de Mestre em Ciências no Programa de Ciências Odontológicas Aplicadas, na área de concentração Dentística.

Orientadora: Profa. Dra. Ana Flávia Sanches Borges 
Mosquim, Victor

Structural, chemical and optical characterizations of an experimental $\mathrm{SiO}_{2}-\mathrm{Y}-\mathrm{TZP}$ ceramic produced by the uniaxial/isostatic pressing technique / Victor Mosquim - Bauru, 2019.

56p. : il. ; $31 \mathrm{~cm}$.

Dissertação (Mestrado) - Faculdade de Odontologia de Bauru. Universidade de São Paulo

Orientador: Profa. Dra. Ana Flávia Sanches Borges

Autorizo, exclusivamente para fins acadêmicos e científicos, a reprodução total ou parcial desta dissertação por processos fotocopiadores e outros meios eletrônicos.

Assinatura: 
FOLHA DE APROVAÇÃO 



\section{DEDICATÓRIA}

Dedico este trabalho à Deus, que me guiou em cada passo da minha trajetória para que esse sonho se concretizasse.

Dedico aos meus pais e irmão, Sergio Mosquim, Elizabete da Silva Mosquim e Sergio Mosquim Júnior, que sonharam esse sonho comigo. A luta diária de vocês faz meus sonhos se realizarem. Vocês me fazem sentir que minha inteligência, meu corpo, minha idade e meu trabalho são suficientes. Escrever essa dissertação é um sonho e um privilégio graças a vocês. Amo vocês indescritivelmente!

Dedico este trabalho à Profa. Dra. Linda Wang, que desde 2014 me orienta com o maior carinho e cuidado. Profa, estou realizando este sonho também graças a você. Não mencionar seu papel no meu desenvolvimento seria como ignorar grande parte da minha paixão pelo que faço. Você me faz ter orgulho das minhas escolhas e de estar na Faculdade de Odontologia de Bauru. Obrigado!

Por fim, à minha orientadora, Profa. Dra. Ana Flávia Sanches Borges, que planejou esse sonho e o ajudou a se tornar realidade. Seu trabalho como professora e orientadora é muito lindo, mas seu caráter como ser humano é excepcional. Conviver com pessoas como você me fazem acreditar num mundo melhor. Muito obrigado! 



\section{AGRADECIMENTOS}

Agradeço aos meus pais, Sergio Mosquim e Elizabete da Silva Mosquim que me ensinam diariamente o poder transformador da educação e do amor; ao meu irmão, Sergio Mosquim Junior, que me ensina a importância do autoconhecimento para realização pessoal.

Ao presente que Deus colocou na minha vida, Gerson Aparecido Foratori Junior. Dividir os dias com você faz a vida mais leve, os sorrisos mais sinceros e a alma mais tranquila. Obrigado por acreditar em mim em cada etapa desse processo e por estar comigo nos momentos mais importantes da minha vida.

Aos amigos com quem tenho o prazer de dividir a dádiva da vida. Mesmo que a vida nos leve à caminhos diferentes e a opiniões divergentes, espero que saibam a importância de vocês e das nossas conversas para nossa constante evolução. Meu amor por vocês é imenso. Obrigado, Giovanna Speranza Zabeu, Mariele Vertuan, Carolina Yoshi Campos Sugio, Thaise Colletti Pavani e João Vitor Ramos dos Santos.

À minha parceira de viagens e de pesquisa, Brunna Mota Ferrairo. Essa pesquisa não seria a mesma sem você. Obrigado por dividir suas experiências e seu conhecimento comigo ao longo dessa etapa.

Às amizades que cresceram na pós-graduação, Letícia Ferreira de Freitas Brianezzi, Natália Almeida Bastos, Lígia Saraiva Bueno, Genine Moreira de Freitas Guimarães, Alyssa Teixeira Obeid, Juliana Carvalho Jacomine, Leandro Edgar Pacheco, Francielly da Silva Camim, Dianela Cristo Santin, Franco Naoki Mezarina Kanashiro, Edgar Massunari Maenosono e Camila Thaís Queiroz. Minha admiração por vocês é imensa, e aprendi muito com cada um de vocês. Desejo o maior sucesso do mundo a todos vocês. 

À minhas tias Lucilena Mosquim e Teresa Cristina Rubin Mota, que cuidaram de mim desde meus primeiros passos, e que fizeram Bauru se tornar um lar desde 2013. Estendo esse agradecimento também ao meu maravilhoso tio-avô Luiz Augusto Mosquim (in memorian), que incentivou meus sonhos desde bebê, e cujo nome me remete ao maior ser humano que eu já conheci. Sei que você está dividindo esse momento comigo.

Aos grandes professores que me inspiraram a amar a Odontologia, e a permanecer na pós-graduação apesar das dificuldades, Profa. Dra. Maria Teresa Atta, Profa. Dra. Daniela Rios, Prof. Dr. Carlos Ferreira dos Santos, Prof. Dr. Estevam Augusto Bonfante, Prof. Dr. José Henrique Rubo, Profa. Dra. Karin Hermana Neppelenbroek e Prof. Dr. Rodrigo Ricci Vivan. Vocês me mostraram que ser professor é uma arte que exige empatia, e talvez isso seja o mais difícil de encontrar nos dias de hoje. Muito obrigado pelas lições, pelo carinho e pela doçura que tiveram com o meu desenvolvimento.

Aos professores com quem tive o prazer de conviver durante a elaboração dessa pesquisa, e que auxiliaram em cada etapa, desde seu planejamento até a elaboração desta dissertação: Prof. Dr. Paulo Noronha Lisboa Filho, Prof. Dr. Aroldo Geraldo Magdalena, Prof. Dr. Carlos Alberto Fortulan e Prof. Dr. Paulo Francisco Cesar.

Ao longo dos meus 6 anos na Faculdade de Odontologia de Bauru tive o privilégio de trabalhar com 3 mulheres que me ensinaram muito mais que o exercício da Odontologia e a importância do professor no desenvolvimento do aluno de graduação. Elas me ensinaram que, apesar de todas as limitações que o Brasil apresenta em relação à Educação, trabalhar com quê e com quem se ama vale a pena. Me ensinaram que cuidar do próximo também é nossa responsabilidade, e me mostraram que o que falta dentro das salas de aula e laboratórios é oportunidade. Vocês me ensinaram que crescer como profissional e ser humano é um processo difícil, mas que olhar para trás é muito gratificante. Espero um dia representar para meus alunos ao menos um pouquinho do que vocês representam para mim. Muito obrigado, Profa. Dra. Linda Wang, Profa. Dra. Ana Carolina Magalhães e Profa. Dra. Ana Flávia Sanches Borges, minha grandiosa conselheira, amiga e orientadora. 

À Faculdade de Odontologia de Bauru - FOB-USP, onde desenvolvi minha formação acadêmica. Nesses 6 anos em que estive aqui (2013-2019) aprendi tudo o que sei hoje. Não tenho palavras para agradecer por todas as oportunidades.

Aos funcionários e professores do Departamento de Dentística e Materiais Dentários. Vocês contribuem diariamente com a formação de cada um dos alunos. Muito obrigado

Às funcionárias da Pós-Graduação e da Clínica de Pós-Graduação. $O$ trabalho de vocês é responsável por fazer a pós-graduação da FOB-USP ter tanta qualidade e eficiência. Muito obrigado.

À Fundação de Amparo à Pesquisa do Estado de São Paulo - FAPESP, pelo apoio financeiro para o desenvolvimento deste trabalho com a concessão da bolsa de mestrado. O presente trabalho foi realizado com apoio da Coordenação de Aperfeiçoamento de Pessoal de Nível Superior - Brasil (CAPES) - Código de Financiamento 001. 

"Liberdade é pouco. O que eu desejo ainda não tem nome." (Clarisse Lispector)

"A história sozinha cria estereótipos, e o problema com estereótipos é que não é que eles não são verdadeiros, mas que eles são incompletos.

Eles fazem uma história se tornar a única história." (Chimamanda Ngozi Adichie)

"A vida para uns são cheias de curvas que dá impressão que eles seguem para o calvário conduzindo uma cruz que se chama "custo de vida'." (Carolina Maria de Jesus) 

ABSTRACT 



\section{ABSTRACT \\ Structural, chemical and optical characterizations of an experimental $\mathrm{SiO}_{2}-\mathrm{Y}$ - TZP ceramic produced by the uniaxial/isostatic pressing technique}

New glass ceramics enriched by polycrystalline materials has been produced by different processing methods. However, for these materials to be used as restorative dental materials in esthetical areas they must count with good optical properties, which are directly influenced by their structure and chemical composition. For these reasons, the aim of this study was to produce a new glass ceramic containing $\mathrm{SiO}_{2}+\mathrm{Y}-\mathrm{TZP}$ via uniaxial/isostatic powder compression and to structurally and chemically characterize this material relating to its optical properties. $\mathrm{SiO}_{2}$ and $\mathrm{Zpex} \circledast$ were used as starting powders. These two powders were mixed (97w\%-3\% ratio) and pressed in uniaxial (80MPa) and isostatic (206MPa) press and sintered at $1150^{\circ} \mathrm{C}$ for $2 \mathrm{~h}$. The starting powders, the mixed powder (before sintering) and the sintered specimens were submitted to Scanning Electron Microscope/Energy Dispersive X-ray Spectroscopy (SEM/EDX), Transmission Electron Microscope (TEM), X-ray Diffraction (XRD) and Fourier Transform Infrared Spectroscopy (FTIR). The material's density was measured. The contrast ratio and translucency parameter of the sintered specimen were compared to lithium disilicate (IPS e.max ${ }^{\circledR}$ CAD HT A1) and zirconia-reinforced lithium silicate (Celtra Duo® HT A1), using Kruskal-Wallis and post-hoc Dunn tests with a significance level set at $5 \%$. Agglomerations of $\mathrm{SiO}_{2}$ and Zpex could be seen under SEM/EDX analysis due to their reduced particle size, yet, when sintered, some remaining porosities could be seen. The TEM analysis evidenced the spherical character of $\mathrm{SiO}_{2}$ grains and the crystallographic pattern of the Zpex particles. When mixed, Zpex can be seen inside the grain of $\mathrm{SiO}_{2}$. XDR analysis pointed out that $\mathrm{SiO}_{2}$ was amorphous, and Zpex presented monoclinic $(m)$ and tetragonal $(t)$ peaks. After sintering, crystallization of $\mathrm{SiO}_{2}$ can be seen without new $m$ peaks. The FTIR spectra bands suggested an interaction between $\mathrm{Si}, \mathrm{O}$ and $\mathrm{Zr}$. The theoretical density value of the experimental ceramics was $1.663 \mathrm{~g} / \mathrm{cm}^{3}$. The contrast ratio and the translucency parameter of the experimental ceramic were higher $(p=0,000001)$ and lower $(p=0,000001)$, respectively, than those of lithium disilicate and zirconia-reinforced lithium silicate. It can be concluded that the uniaxial/isostatic powder compression is an efficient method to obtain experimental ceramics for dental purposes and $1150^{\circ} \mathrm{C}$ for $2 \mathrm{~h}$ is sufficient to crystallize $\mathrm{SiO}_{2}$ without inducing $t-m$ transformation of zirconia. Yet, this sintering protocol seems to be insufficient to densify the experimental ceramic, which may the reason for its lack of translucency.

Key words: Ceramics. Silicon dioxide. Zirconium. 




\section{RESUMO}

\section{Caracterizações estrutural, química e óptica de uma cerâmica experimental de $\mathrm{SiO}_{2}$-Y-TZP produzida pela técnica de prensagem uniaxial/isostática}

Novas cerâmicas vítreas enriquecidas por materiais policristalinos tem sido produzidas por diferentes métodos de processamento. Entretanto, para que sejam utilizados como materiais restauradores odontológicos em áreas estéticas, eles devem apresentar boas propriedades ópticas, que estão diretamente influenciadas por sua estrutura e composição química. Por esses motivos, o objetivo deste estudo foi produzir uma nova cerâmica vítrea contendo $\mathrm{SiO}_{2}+\mathrm{Y}$-TZP através da via uniaxial/isostática, e caracterizar este material estrutural e quimicamente, relacionando às suas propriedades ópticas. $\mathrm{SiO}_{2}$ e $\mathrm{Zpex} \circledast$ foram usados como pós de partida, misturados ( $97 \mathrm{~m} \%-3 \mathrm{~m} \%$ ), prensados em prensa uniaxial (80MPa) e isostática (206MPa) e sinterizados à $1150^{\circ} \mathrm{C}$ por $2 \mathrm{~h}$. Os pós de partida, o pó após a mistura (prévio à sinterização) e a amostra sinterizada foram submetidos à Microscopia Eletrônica de Varredura/Espectroscopia por Energia Dispersiva de Raios-X (MEV-EDX), Microscopia Eletrônica de Transmissão (MET), Difração de Raios-X (DRX) e Espectroscopia de Infravermelho com Transformada de Fourier (FTIR). A densidade do material foi mensurada. A razão de contraste e o parâmetro de translucidez da amostra sinterizada foram comparados aos do dissilicato de lítio (IPS e.max® CAD HT A1) e do silicato de lítio reforçado por zircônia (Celtra Duo® HT A1), utilizando os testes de Kruskal-Wallis e post-hoc Dunn com nível de significância de 5\%. Aglomerações $\mathrm{SiO}_{2}$ e Zpex foram vistas sob MEV/EDX devido ao tamanho reduzido das partículas, porém, quando sinterizado, algumas porosidades puderam ser vistas. A análise em MET evidenciou o caráter esférico dos grãos de $\mathrm{SiO}_{2}$ e o padrão cristalográfico das partículas de Zpex. Quando misturados, Zpex pode ser visto dentro de uma partícula de $\mathrm{SiO}_{2}$. A análise em DRX destacou que a $\mathrm{SiO}_{2}$ era amorfo e Zpex apresentava picos monoclínicos $(m)$ e tetragonais $(t)$. Após a sinterização, a cristalização da $\mathrm{SiO}_{2}$ pode ser vista sem a formação de novos picos $m$. As bandas do espectro do FTIR sugeriram uma interação entre $\mathrm{Si}$, O e Zr. A densidade do material foi $1,663 \mathrm{~g} / \mathrm{cm}^{3}$. A razão de contraste e o parâmetro de translucidez da cerâmica foi maior $(p=0,000001)$ e menor $(p=0,000001)$, respectivamente, que os do silicato de lítio e do silicato de lítio reforçado por zircônia. Podese concluir que a compressão dos pós em prensa uniaxial/isostática é um método eficiente em produzir cerâmicas experimentais para uso odontológico, e que $1150^{\circ} \mathrm{C}$ por $2 \mathrm{~h}$ é suficiente para cristalizar o $\mathrm{SiO}_{2}$ sem induzir transformação $t-m$ na zirconia. Contudo, esse protocolo de sinterização parece ser insuficiente para densificar a cerâmica experimental, o que pode prejudicar sua translucidez.

Palavras-chave: Cerâmica. Dióxido de silício. Zircônio 



\section{LIST OF ILLUSTRATIONS}

Figure 1 - Heating rate at which the specimens of the experimental group were submitted during sintering

Figure 2 - SEM assessment conducted on the initial silica powder (A); on the Zpex initial powder (B) and on a fracture area of a specimen after sintering (C). The EDX analysis was conducted on both silica (D) and Zpex (E)

Figure 3 - Transmission Electronic Microscope (TEM) images of the silica powder in $A, B$ and $C$, where it can be stated that silica particles were spherical and amorphous due to the lack of a crystallographic pattern. In $D, E, F$ and $G$ the images obtained by the analysis of Zpex. Lowmagnification TEM image is seen in $\mathrm{D}$, and in $\mathrm{E}$ the corresponding FFT pattern of a single nanoparticle, and the crystallographic pattern of a single nanoparticle in $\mathrm{F}$ and $\mathrm{G}$. In $\mathrm{H}$ and $\mathrm{I}$, the images were obtained before sintering the material (physical mixture), where the Zpex particle can be seen in the silica particle $(\mathrm{H}$ and $\mathrm{I})$

Figure 4 - XRD patterns of the sample before and after sintering at $1150^{\circ} \mathrm{C}$ for $2 \mathrm{~h}$

Figure 5 - FTIR spectra of the sample before and after sintering at $1150^{\circ} \mathrm{C}$ for $2 \mathrm{~h}$. 



\section{LIST OF TABLES}

Table 1 - Classification and composition of the ceramics used in this study .......26

Table $2-\mathrm{CR}$ and $\Delta \mathrm{E}$ values obtained after the statistical analysis...................33 



\section{TABLE OF CONTENTS}

$1 \quad$ INTRODUCTION

2 ARTICLE

3 DISCUSSION

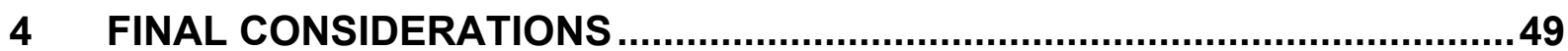

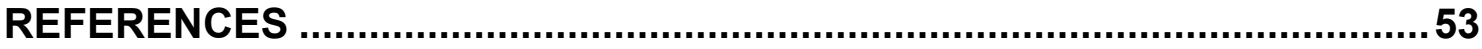



1 INTRODUCTION 



\section{INTRODUCTION}

Dental ceramics are used as restorative materials due to their inherited properties, such as the color stability, resistance to wear, high strength, biocompatibility and low biofilm accumulation (KELLY, BENETTI, 2011; AMOROSO et al., 2012). Polycrystalline ceramics, such as zirconia $\left(\mathrm{ZrO}_{2}\right)$ owns a much higher fracture toughness than glass ceramics, which in turn are much more translucent and esthetically appealing. These characteristics are important to be taken into consideration depending on the area these materials are being indicated by the dental practitioner.

In glass ceramics, silicon oxide $\left(\mathrm{SiO}_{2}\right)$ is often present (KELLY, 2008; KELLY, BENETTI, 2011), and, as an attempt to enhance the mechanical properties of glass ceramics, crystalline materials, such as $\mathrm{ZrO}_{2}$ are used to enrich these materials (KELLY, 2008; KELLY, BENETTI, 2011). Zirconia can be found at three allotropic phases: monoclinic $(m)$, tetragonal $(t)$ and cubic $(c)$. Under room temperature until $1,170^{\circ} \mathrm{C}$ the monoclinic phase of $\mathrm{ZrO}_{2}$ is found. From 1,170 until $2,370^{\circ} \mathrm{C} \mathrm{Zr}_{2}$ is in its tetragonal form, and above that temperature, in cubic form (CHEVALIER, GREMILLARD, DEVILLE, 2007; KELLY, DENRY, 2008; EL-GAHNY, SHERIEF, 2016). The tetragonal to monoclinic $(t-m)$ transformation result in $4.5 \%$ volumetric expansion, which is held responsible for the higher fracture toughness of zirconia when in its tetragonal form. Hence, with the intention to stabilize $t$-zirconia under room temperature, dopants such as yttrium oxide $\left(\mathrm{Y}_{2} \mathrm{O}_{3}\right)$ are used, originating yttriastabilized tetragonal zirconia (Y-TZP) (GUAZATTO et al., 2004; RAMOS et al., 2015). However, as the zirconia/Y-TZP is known to be opaque, its use in esthetical areas is limited. Therefore, new ceramic materials containing $\mathrm{SiO}_{2}$ and enriched by $\mathrm{ZrO}_{2} / \mathrm{Y}-\mathrm{TZP}$ has been processed by many different routes, such as sol-gel, slip-casting and uniaxial/isostatic powder compression and in order to achieve good optical properties (MOUZON, GLOWACKI, ODÉN, 2008; JIANG et al., 2011; PERSSON et al., 2012).

The uniaxial/isostatic powder compression technique is used to produce ceramic materials using powders as starting points. This technique is based on applying pressure to a mold so the powder in it can be compressed. Thereafter, this green-body material is submitted to a sintering protocol with an attempt to density the 
material. Densification is important to reduce porosities, irregularities and internal spaces generated during the fabrication method (MCCABE, WALLS, 2008; VOLPATO et al., 2011), which are also related to the transmittance of light inside the materials bulk (JIANG et al., 2011). Also, nano-sized powders are used in order to generate more uniform and smoother surfaces, which, associated with proper heating protocols could lead to proper light transmittance, i.e., translucency.

Translucency can be defined as the amount of light that is transmitted or reflected from a materials surface through a turbid medium (BRODBELT, O'BRIEN, FAN, 1980). As shown in previous studies, the size, the amount of crystals in the material and also its porosity play important roles regarding the amount of light transmitted through the material (HEFFERNAN et al., 2002; JIANG et al., 2011), consequently interfering in the translucency of a given substrate. For these reasons, the amount of crystalline content in the materials composition can lead to low translucency due to different refractive indices between the matrix and the crystals used for enrichment purposes, leading to scattering and diffuse reflection of light, resulting in undesired opaqueness (JIANG et al., 2011).

Considering these obstacles at reaching proper translucency, the processing methods play an important role at achieving the desired optical properties (MOUZON, GLOWACKI, ODÉN, 2008; JIANG et al., 2011; PERSSON et al., 2012). Though, these processing methods used to obtain experimental ceramics are not commonly used to create ceramics with dental purposes, justifying the need to structurally characterize the materials produced by them and evaluate their desired properties. Therefore, since new glass ceramics enriched by polycrystalline materials has been produced by different processing methods and achieved interesting results, the aim of this study was to produce a new glass ceramic containing $\mathrm{SiO}_{2}+\mathrm{Y}-\mathrm{TZP}$ via uniaxial/isostatic powder compression and structurally and chemically characterize this material relating to its optical properties. 
2 ARTICLE 



\section{ARTICLE}

The article presented in this Dissertation was written according to the Journal of the European Ceramic Society instructions and guidelines for article submission. 


\title{
Structural, chemical and optical characterizations of an experimental SiO2-Y- TZP ceramic produced by the uniaxial/isostatic pressing technique
}

\begin{abstract}
This study produced a new $\mathrm{SiO}_{2}+\mathrm{Y}-\mathrm{TZP}$ ceramic via uniaxial/isostatic compression and structurally and chemically characterized it relating to its translucency. $\mathrm{SiO}_{2}$ and Zpex® were mixed, pressed and sintered at $1150^{\circ} \mathrm{C}$. The starting powders, the mixed powder (before sintering) and the sintered specimens were submitted to Scanning Electron Microscope, Transmission Electron Microscope, X-ray Diffraction and Fourier Transform Infrared Spectroscopy (FTIR). The contrast ratio (CR) and translucency parameter (TP) were compared to lithium disilicate and Celtra Duo® (Kruskal-Wallis, $\alpha=0.05)$. Before sintering, Zpex grains were inside $\mathrm{SiO}_{2}$ and, after sintering, some remaining porosities were present. $\mathrm{SiO}_{2}$ was crystallized without $t-m$ transformation in Zpex. The FTIR bands suggested an interaction between $\mathrm{Si}, \mathrm{O}$ and $\mathrm{Zr}$. CR and TP of the experimental ceramic were higher and lower, $(p=0,000001)$ respectively, than those the commercialized glass-ceramics. In conclusion, this processing method is efficient to obtain a $\mathrm{SiO}_{2}+\mathrm{Y}-\mathrm{TZP}$ ceramic and $1150^{\circ} \mathrm{C}$ crystallizes $\mathrm{SiO}_{2}$ without inducing $t-m$ transformation.
\end{abstract}

Key words: Ceramics. Silicon dioxide. Zirconium. 


\section{Introduction}

Dental ceramics are used as restorative materials due to their inherited properties, such as the color stability, resistance to wear, high strength, biocompatibility and low biofilm accumulation [1-2]. Polycrystalline ceramics, such as zirconia $\left(\mathrm{ZrO}_{2}\right)$ owns a much higher fracture toughness than glass ceramics, which in turn are much more translucent and esthetically appealing. These characteristics are important to be taken into consideration depending on the area these materials are being indicated by the dental practitioner.

In glass ceramics, silicon oxide $\left(\mathrm{SiO}_{2}\right)$ is often present [1,3], and, as an attempt to enhance the mechanical properties of glass ceramics, crystalline materials, such as $\mathrm{ZrO}_{2}$ are used to enrich these materials [1,3]. Zirconia can be found at three allotropic phases: monoclinic $(\mathrm{m})$, tetragonal $(\mathrm{t})$ and cubic $(\mathrm{c})$. Under room temperature until $1,170^{\circ} \mathrm{C}$ the monoclinic phase can be seen. From 1.170 until $2,370^{\circ} \mathrm{C} \mathrm{ZrO}_{2}$ is in its tetragonal form, and above that temperature, in cubic form [4-6]. The tetragonal to monoclinic (t-m) transformation result in $4.5 \%$ volumetric expansion, which is held responsible for the higher fracture toughness of zirconia when in its tetragonal form. Hence, with the intention to stabilize t-zirconia under room temperature, dopants such as yttrium oxide $\left(\mathrm{Y}_{2} \mathrm{O}_{3}\right)$ are used, originating yttria-stabilized tetragonal zirconia ( $\mathrm{Y}$ TZP) [7-8]. However, as the zirconia/Y-TZP is known to be opaque, its use in esthetical areas is limited. Therefore, new ceramic materials containing $\mathrm{SiO}_{2}$ and enriched by $\mathrm{ZrO}_{2} / \mathrm{Y}-\mathrm{TZP}$ has been processed by many different routes, such as sol-gel, slip-casting and uniaxial/isostatic powder compression and in order to achieve good optical properties [9-11].

The uniaxial/isostatic powder compression technique is used to produce ceramic materials using powders as starting points. This technique is based on applying pressure to a mold so the powder in it can be compressed. Thereafter, this green-body material is submitted to a sintering protocol with an attempt to density the material. Densification is important to reduce porosities, irregularities and internal spaces generated during the fabrication method [12-13], which are also related to the transmittance of light inside the materials bulk [10]. Also, nano-sized powders are used in order to generate more uniform and smoother surfaces, which, associated with proper heating protocols could lead to proper light transmittance, i.e., translucency. 
Translucency can be defined as the amount of light that is transmitted or reflected from a materials surface through a turbid medium [14]. As shown in previous studies, the size, the amount of crystals in the material and also its porosity play important roles regarding the amount of light transmitted through the material [10, 15], consequently interfering in the translucency of a given substrate. For these reasons, the amount of crystalline content in the materials composition can lead to low translucency due to different refractive indices between the matrix and the crystals used for enrichment purposes, leading to scattering and diffuse reflection of light, resulting in undesired opaqueness [10].

Considering these obstacles at reaching proper translucency, the processing methods play an important role at achieving the desired optical properties [9-11]. Though, these processing methods used to obtain experimental ceramics are not commonly used to create ceramics with dental purposes, justifying the need to structurally characterize the materials produced by them and evaluate their desired properties. Therefore, since new glass ceramics enriched by polycrystalline materials has been produced by different processing methods and achieved interesting results, the aim of this study was to produce a new glass ceramic containing $\mathrm{SiO}_{2}+\mathrm{Y}-\mathrm{TZP}$ via uniaxial/isostatic powder compression and structurally and chemically characterize this material relating to its optical properties.

\section{Materials and Methods}

\section{1 - SYNTHESIS OF SILICA}

The synthesis of silica from tetraethyl orthosilicate (TEOS, 99.9\%) was performed according to the methodology used by Li et al. (2012), from the modified Stöber method. This method consists in adding $10 \mathrm{~mL}$ of milli-q water and $4 \mathrm{~mL}$ of TEOS to a beaker, which was maintained in an ultrasonic machine for 5 minutes to allow the emulsion of the reagents. Then, $50 \mathrm{~mL}$ of absolute alcohol $\left(\mathrm{C}_{2} \mathrm{H}_{5} \mathrm{OH}, 99.5 \%\right)$ was dispensed into the beaker, followed by $15 \mathrm{~mL}$ of $\mathrm{NH}_{4} \mathrm{OH}$, which were dripped into the solution under magnetic stirring $(400 \mathrm{rpm})$ at $40^{\circ} \mathrm{C}$ to allow the hydrolysis of TEOS. The reaction was maintained for 6 hours to obtain the white, amorphous silica suspension. 
The obtained silica and the powder of partially stabilized polycrystalline tetragonal zirconia (Zpex) containing $5.2 \pm 0.2$ wt\% $\mathrm{Y}_{2} \mathrm{O}_{3}$ (Tosoh Corporation, Tokyo, Japan; batch no. Z306234P; surface area of $15.1 \mathrm{~m} 2 / \mathrm{g}$ ) were morphologically, chemically and structurally analyzed by Scanning Electron Microscope/Energy Dispersive X-ray Spectroscopy (SEM/EDX), by X-ray Diffraction (XRD), by a Transmission Electron Microscope (TEM) and by Fourier Transform Infrared Spectroscopy (FTIR).

\subsection{1 - Scanning Electron Microscope/Energy Dispersive X-ray Spectroscopy (SEM/EDX)}

Energy Dispersive X-ray Spectroscopy (EDX) was performed using a Scanning Electron Microscope (SEM) (JEOL-JSM 5600LV, Tokyo, Japan) equipped with an Xray detector (Voyager, Noran Instruments), vacuum and in backscattered electron mode.

\subsection{2 - Transmission Electron Microscope (TEM)}

The silica and the Zpex powders were observed in Transmission Electron Microscope (TEM) (CM200 model, Philips, Amsterdam, Netherlands) with a LaB6 filament (lanthanum hexaboride) and operated at a maximum voltage of $200 \mathrm{kV}$.

\subsection{3 - X-ray Diffraction (XRD)}

The X-ray diffractometer (Shimadzu model XDR 7000, Kyoto, Japan) was used with $\mathrm{Cu}$ Ka radiation, angular scan between $10^{\circ}$ and $70^{\circ}$, with a scan speed of 2 min $^{-}$ 1. New analyses were performed after the synthesis of the experimental ceramic, following the specifications of each method, as follows.

The crystalline phases of the initial Zpex powder were identified and the amorphous characteristic of the initial silica powder was validated by $\mathrm{x}$-ray diffraction. After sintering the experimental ceramic, a sample underwent a XRD analysis as well.

The crystalline phases were identified by comparing the spectra obtained with the standard datasheets of the Joint Committee on Powder Diffraction Standards (JCPDS) using the Crystalographica Search-Match software.

The Scherrer equation was used to calculate the particles size of the silica powder $(d)$ in which, $k$ is the shape constant $(\approx 0.9), \lambda$ corresponds to ka Cu $(\mathrm{k \alpha})$, 
$\lambda=1,54060 \AA, B$ is full width at half-maximum of the diffraction peak, and $\theta$ is the Bragg angle.

$d=\frac{(k \times \lambda)}{(B \times \cos \theta)}$

Equation 1

\subsection{4 - Fourier Transform Infrared Spectroscopy (FTIR)}

The initial Zpex powder and the silica powder $(\approx 0.5 \mathrm{~g}, \mathrm{n}=3)$ were placed on an FTIR spectrometer (Shimadzu Corporation, Model IR Prestige 21, Kyoto, Honshu, Japan) attached to a ATR device (Smart Miracle ${ }^{T M}$ containing a diamond plate, Pike Technologies, Madison, Wisconsin, USA). Before each reading, each powder was compressed against the ATR diamond crystal using a micrometric low-pressure clamp (408 psi) to allow optimal contact with it. The transmittance spectra were obtained between 4000 and $450 \mathrm{~cm}^{-1}$ with 32 scans at $4 \mathrm{~cm}^{-1}$. After sintering, one specimen was taken to the FTIR spectrometer to be analyzed following the same parameters described above.

\section{3 - SAMPLE ACQUISITION}

\subsection{1 - Experimental ceramic (Zpex + silica)}

The experimental ceramic was obtained using the commercial Zpex® injection powder on a nanometric scale $(0.04 \mu \mathrm{m})$ containing $\mathrm{Y}_{2} \mathrm{O}_{3}(5.35 \pm 0.2 \mathrm{wt} \%), \mathrm{HfO}_{2}(<5.0$ wt $\%$ ), $\mathrm{Al}_{2} \mathrm{O}_{3}$ ( $\leq 0.1 \mathrm{wt} \%$ ), $\mathrm{Na}_{2} \mathrm{O}$ ( $\leq 0.04$ wt\%), $\mathrm{SiO}_{2}$ ( $\left.\leq 0.02 \mathrm{wt} \%\right), \mathrm{Fe}_{2} \mathrm{O}_{3}(\leq 0.01 \mathrm{wt} \%)$ (Zpex, Tosoh Corporation, Tokyo, Japan) and the aforementioned silica powder. This mixture respected a 97-03 wt\% ratio (Silica-Zpex).

The Zpex and silica powders were placed in a polyethylene jug, which was filled with $28.25 \mathrm{~g}$ of isopropyl alcohol, $513 \mathrm{~g}$ of $\mathrm{ZnO}_{2}$ spheres and $0.145 \mathrm{~g}$ of polyvinyl butyral (PVB). Then the jug was kept in a rotatory mill for 2 hours. After that time, $1.305 \mathrm{~g}$ of polyvinyl butyral (PVB) diluted into $26.1 \mathrm{~g}$ of isopropyl alcohol were inserted into the mixture and the jug was again kept in a rotatory mill for another 10 minutes.

Thereafter, the contents of the jug were dried and sieved through a $180 \mu \mathrm{m}$ sieve. The mixture was compacted in a metal device previously lubricated with oleic acid to obtain cold uniaxial compression bars at $80 \mathrm{MPa}$. The bars were subjected to isostatic compress at $206 \mathrm{MPa}$ for $1 \mathrm{~min}$ and then sintered at $1150^{\circ} \mathrm{C}$ in a $\mathrm{MoSi}_{2}$ furnace for $2 \mathrm{~h}$, with a heating rate displayed in figure 1 . 


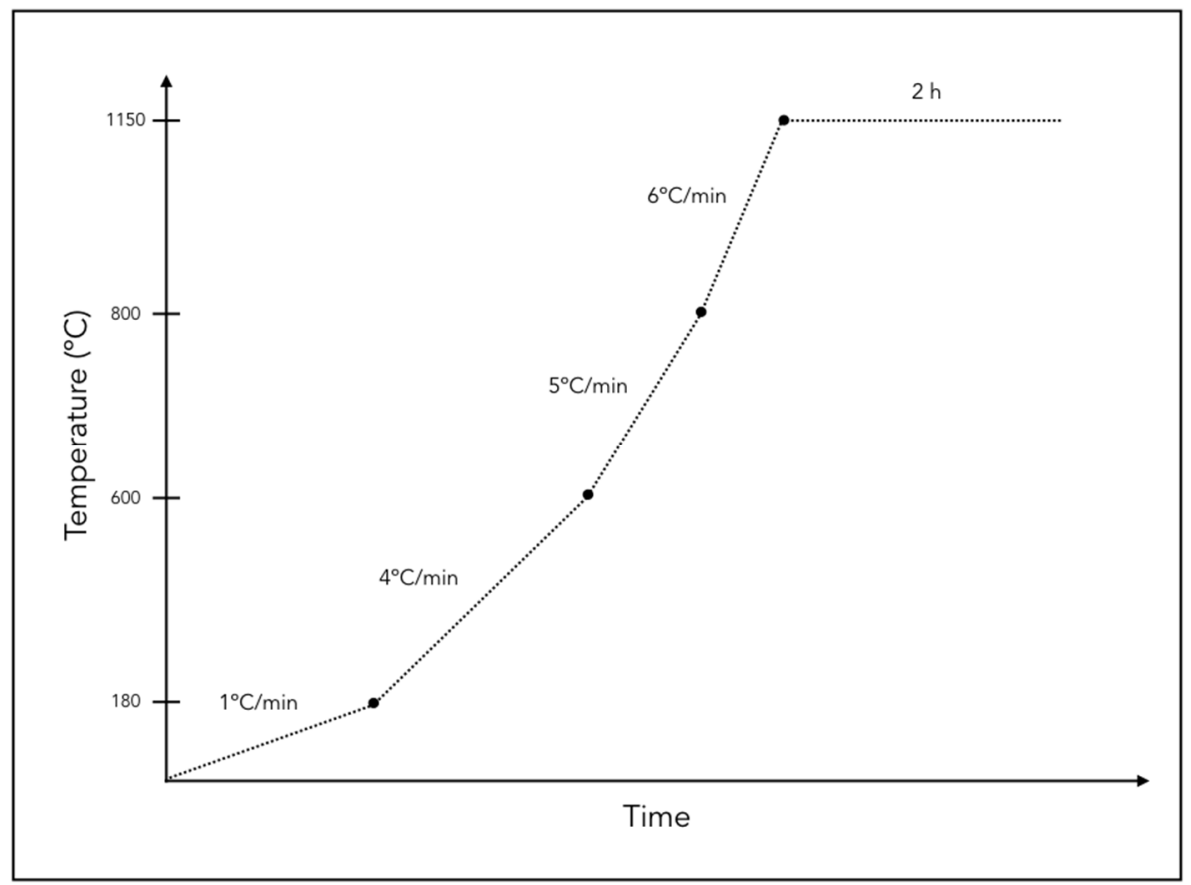

Figure 1: Heating rate at which the specimens of the experimental group were submitted during sintering.

\section{4 - THEORETICAL DENSITY ANALYSIS}

Five specimens were submitted to a theoretical density analysis, which is based on Archimedes's principle. For that, each sample was weighted on an analytical scale (Adventurer Analytical balance, Ohaus, Parsippany, NJ, USA) when dried, underwater and after immersed in water for 24 hours. This method was used to estimate the density of the Silica-Zpex experimental ceramic after sintering.

\section{5 - OPTICAL PROPERTIES TEST}

\subsection{1 - Sample acquisition (silica + Zpex, IPS e.max CAD® and Celtra Duo®)}

Ten bars of the experimental ceramic (silica + Zpex), one lithium disilicate (IPS e.max $\mathrm{CAD} \otimes$, Ivoclar Vivadent, Schaan, Liechtenstein) C14 HT A1 block and one zirconium-reinforced lithium silicate C14 HT A1 block (Celtra Duo®, Dentsply, York, Pennsylvania, USA) were stabilized on an Isomet 1000 digital cutting machine (Buehler, LakeBluff, IL, USA). Using a diamond wafering blade (Extec XL12205 High Concentration, Extec Corp., Enfield, Connecticut, USA) at 300 rpm under refrigeration, the specimens were cut into $5 \mathrm{~mm}$ wide $\times 7 \mathrm{~mm}$ high and $2 \mathrm{~mm}$ thick ( $\mathrm{n}=10$ /group). 
After cutting, the lithium disilicate specimens were taken to a furnace (Programat EP3000, Ivoclar Vivadent, Schaan, Liechtenstein) for crystallization according to the manufacturer's recommendations in order to obtain their final optical properties.

\subsection{2 - Division into groups}

For the study 30 specimens were used in the dimensions of $5 \mathrm{~mm}$ wide $\times 7 \mathrm{~mm}$ high and $2 \mathrm{~mm}$ thick, totaling 10 specimens for each material ( $\mathrm{n}=10 / \mathrm{group}$ ). The materials were divided into 3 groups, as described in Table 1.

Table 1: Classification and composition of the ceramics used in this study.

\begin{tabular}{|c|c|c|c|}
\hline GROUP & MATERIAL & CLASSIFICATION & COMPOSITION \\
\hline ESY & $\begin{array}{l}\text { Experimental ceramic } \\
\text { containing silica and } \\
\text { Zpex nanoparticles }\end{array}$ & $\begin{array}{l}\text { Silica reinforced with } \\
3 \% \text { of Zpex }\end{array}$ & $\begin{array}{l}3 \% \text { ZPEX } \\
5 \% \text { PVB } \\
97 \% \text { SILICA }\end{array}$ \\
\hline MAX & IPS e.max CAD® & Lithium disilicate & $\begin{array}{l}57-80 \% \mathrm{SiO}_{2} \\
11-19 \% \mathrm{Li}_{2} \mathrm{O} \\
0-13 \% \mathrm{~K}_{2} \mathrm{O} \\
0-11 \% \mathrm{P}_{2} \mathrm{O}_{5} \\
0-8 \% \mathrm{ZrO}_{2} \\
0-8 \% \mathrm{ZnO} \\
0-5 \% \mathrm{Al}_{2} \mathrm{O}_{3} \\
0-5 \% \mathrm{MgO}^{2}\end{array}$ \\
\hline CD & Celtra Duo® & $\begin{array}{l}\text { Zirconia-reinforced } \\
\text { lithium silicate }\end{array}$ & $\begin{array}{l}\text { Lithium silicate with } \\
\text { approximately } 10 \% \text { of } \\
\mathrm{ZrO}_{2}\end{array}$ \\
\hline
\end{tabular}

The optical properties of each material were tested on a CM 3700d spectrophotometer (Konica Minolta, Tokyo, Japan), whose wavelength (400nm to $700 \mathrm{~nm}$ with intervals of $10 \mathrm{~nm}$ ) lies in the visible light spectrum and is emitted by a xenon arc lamp. For this test, each specimen was polished using a semi-automatic polishing machine (Automet 2000, Buehler, Lake Bluff, IL, USA) with 45, 15, 9, 6, 3 and $1 \mu \mathrm{m}$ granulated diamond disks (Allied High Tech Products, Rancho Dominguez, CA, USA) with diamond suspensions up to $1 \mu \mathrm{m}$. Then, they were positioned in the 
equipment with the $35 \mathrm{~mm}^{2}$ side facing the light source. Thus, the ten specimens of each group were analyzed only once, acquiring values following the CIELab* (Commission Internationale de l'Éclairage / International Commission of Illumination) parameter on white background ( $\mathrm{Yw}$ ) and on black background (Yb). From these data, the contrast ratio (CR) and the translucency parameter (TP) were calculated, as performed by Nogueira and Della Bona [16], and dos Santos et al. [17].

The contrast ratio (CR) corresponds to the property that measures transparency $(C R=0)$ and opacity $(C R=1)$ of the material obtained through the ratio between the reflectance of the specimen, both on the black background $(\mathrm{Yb})$ and on the white background $(\mathrm{Yw})[16,18]$, which is given by:

$C R=Y b / Y w$

Equation 2

The masking ability of the material corresponds to the translucency parameter (TP). This data was obtained by calculating the color difference $(\Delta \mathrm{E})$, which was calculated from the $L$ *,$a$ * and $b$ * parameters of the material on the black and white backgrounds $[16,18,19]$. The value of $\Delta E$ was calculated from the following equation:

$\Delta E=\left[\left(L^{*}{ }_{b}-L^{*} w\right)^{2}+\left(a^{*}{ }_{b}-a^{*}{ }_{w}\right)^{2}+\left(b^{*}{ }_{b}-b^{*}{ }^{*}\right)^{2}\right]^{1 / 2}$

Equation 3

The subscripts $b^{*}$ (black) and $w^{*}$ (white) correspond to the color of the background on which the specimen was positioned in the spectrophotometer.

\section{6 - STATISTICAL ANALYSIS}

The data were organized on Excel spreadsheets and statistically analyzed using IBM SPSS software (SPSS Inc., Chicago, IL, USA). The normal distribution of data was checked using the Kolmogorov-Smirnov test. As there was no normal distribution, Kruskal-Wallis followed by post-hoc Dunn tests were applied. All analyses were performed with the level of significance set at $5 \%$.

\section{Results}

3.1 - Scanning Electron Microscope/Energy Dispersive X-ray Spectroscopy (SEM/EDX) 
The chemical characterization of Zpex and silica was conducted using a Scanning Electron Microscope / Energy Dispersive X-ray Spectroscopy (SEM/EDX). The analysis conducted on silica detected small agglomerations of smaller spherical primary particles of silica, (Figure 2A). Also, the EDX analysis detected silicon (Si) and oxygen (O), in $47.88 \mathrm{w} \%$ and $52.12 \mathrm{w} \%$, respectively (Figure $2 \mathrm{D}$ ).

As performed on silica, the Zpex powder was also submitted to the same analysis. The SEM analysis indicated several agglomerations of the nano-sized particles (Figure 2B). The EDX assessment indicated the presence of mainly four chemical elements: zirconium $(\mathrm{Zr})$, oxygen $(\mathrm{O})$ and yttrium $(\mathrm{Y})$ and hafnium $(\mathrm{Hf})$ in $67.06 \mathrm{w} \%, 27.79 \mathrm{w} \%, 4.19 \mathrm{w} \%$ and $0.95 \mathrm{w} \%$, respectively (Figure $2 \mathrm{E}$ ).

After sintering, MEV was conducted on a fracture area (Figure 2C). In this area it is possible to notice the densification of the sample and the presence of silica grains, characterized by their spherical character.

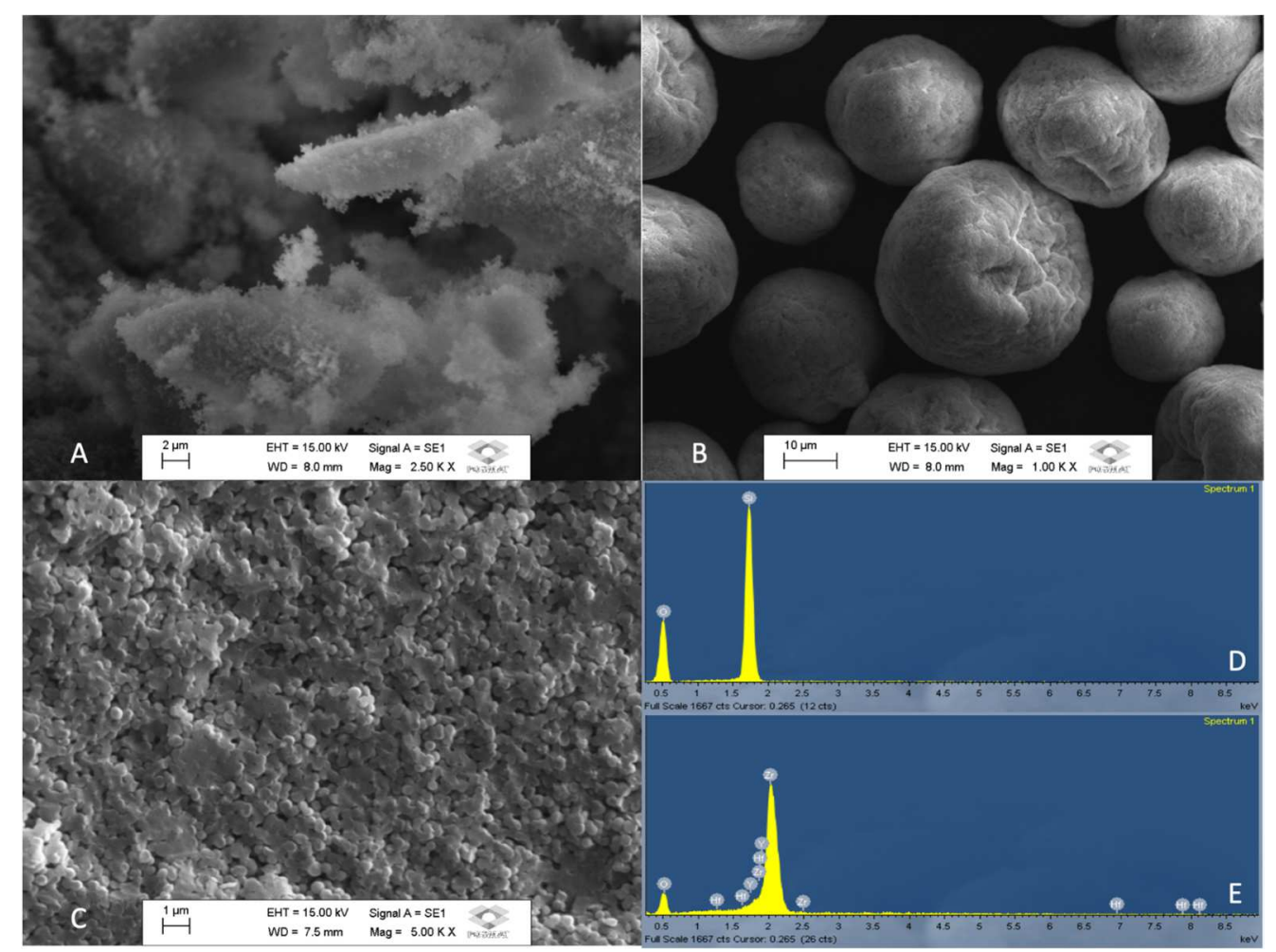

Figure 2: SEM assessment conducted on the initial silica powder (A); on the Zpex initial powder (B) and on a fracture area of a specimen after sintering (C). The EDX analysis was conducted on both silica (D) and Zpex (E). 


\section{2 - Transmission Electron Microscopy (TEM)}

Silica was obtained from tetraethyl orthosilicate (TEOS) by the modified Stöber method, as described above. This method allows the hydrolysis and condensation of this material into silica powder. This powder was also submitted to TEM analysis, where it was possible to confirm that the particles were spherical and amorphous (Figure 3A, 3B and 3C).

The Zpex powder is commercialized in a 40nm scale, therefore a TEM analysis was necessary to properly confirm this statement. Under the TEM analysis, it was possible to observe the heterogeneity of the sample, both in the particles' shape and size (Figure 3D, 3E, 3F, 3G).

After mixing the two powder in the determined proportion, the resulting powder was taken to an analysis under TEM. In the acquired images, a particle of Zpex can be seen inside the grain of silica (Figure $3 \mathrm{H}$ and $3 \mathrm{l}$ ). Also, the amorphous character of silica can be seen due to the lack of a crystallographic pattern, different from Zpex, which owns crystallographic patterns, seen in Figures $3 F$ and $3 G$

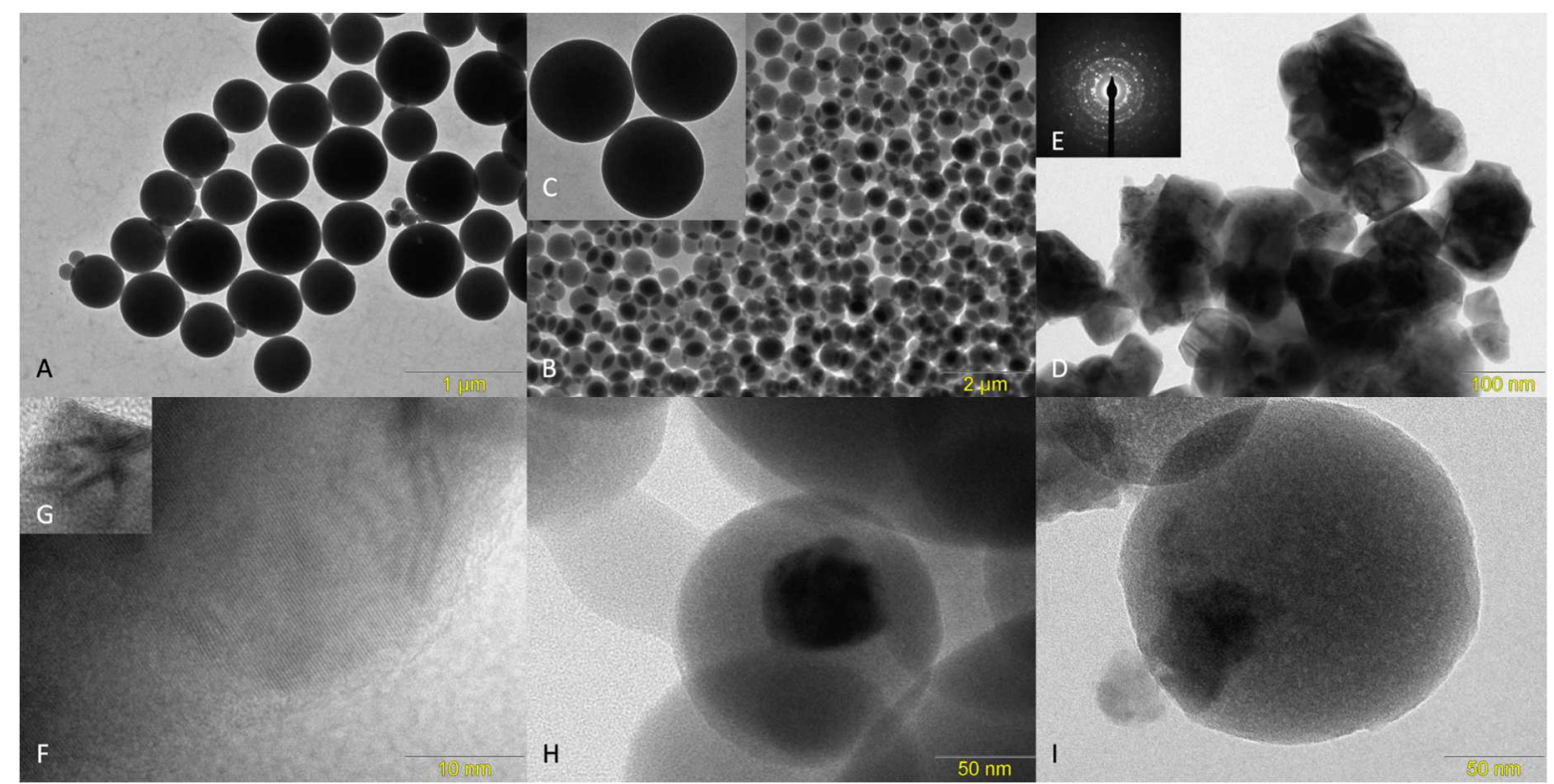

Figure 3: Transmission Electronic Microscope (TEM) images of the silica powder in A, $\mathrm{B}$ and $\mathrm{C}$, where it can be stated that silica particles were spherical and amorphous due to the lack of a crystallographic pattern. In D, E, F and $G$ the images obtained by the analysis of Zpex. Low-magnification TEM image is seen in $D$, and in $E$ the corresponding FFT pattern of a single nanoparticle, and the crystallographic pattern of 
a single nanoparticle in $\mathrm{F}$ and $\mathrm{G}$. In $\mathrm{H}$ and $\mathrm{I}$, the images were obtained before sintering the material (physical mixture), where the Zpex particle can be seen in the silica particle (H and $\mathrm{I})$.

\section{3 - X-ray Diffraction $(X R D)$}

The structural analysis was conducted by X-ray Diffraction (XRD). According to the standard datasheets of the Joint Committee on Powder Diffraction Standards (JCPDS), this structural analysis showed that the silica acquired by the modified Stöber method is amorphous (Figure 3). In addition, through the Scherrer equation it was possible to verify that the particles size was about $1.8 \mathrm{~nm}$.

The structural analysis was also performed on the Zpex powder. This analysis is expressed in Figure 3, where more intense peaks are seen in the region of 28, 31 and 35 degrees, attributed to the monoclinic phase of $\mathrm{ZrO}_{2}$, whilst the ones at 30, 50 and 60 degrees can be attributed to the tetragonal phase. Less intense peaks are also seen at 24, 40, 53, 55 and 62 and are to the monoclinic phase, excepting 55 degrees, which can also be attributed to the tetragonal allotropic phase (Figure 4) [20-21]. In this case, unlike what is stated by the manufacturer, the powder is not commercialized solely in its tetragonal form.

The Zpex and silica powders were mixed in a ball-mill in the proportions described above. Before being submitted to the sintering treatment, it was analyzed structurally. The graph that resulted from this analysis corresponded to an overlapping of the amorphous characteristic attributed to the silica powder and the peaks attributed to the Zpex powder. However, the intensity of the peaks detected at 28, 30, 35, 50 and 60 degrees decreased, and the ones located at 53 and 55 were eliminated. Also, the peaks at 24 and 31 were dislocated to 26 and 33 degrees, respectively (Figure 4). This dislocation can be associated with the formation of $\mathrm{ZrSiO}_{4}$ [20].

After sintering at $1150^{\circ} \mathrm{C}$ for 2 hours, it can be stated that the temperature at which the specimens were sintered was sufficient to crystallize the amorphous silica, once a new peak at the 22 degrees can be seen [22]. Also, a delicate new peak can be seen at 36 degrees, attributed to the formation of $\mathrm{ZrSiO}_{4}$ [20]. All other peaks related to Zpex were eliminated, excepting the ones at 30 and 60 degrees, which are representing the tetragonal allotropic phase of $\mathrm{ZrO}_{2}$ (Figure 4). 


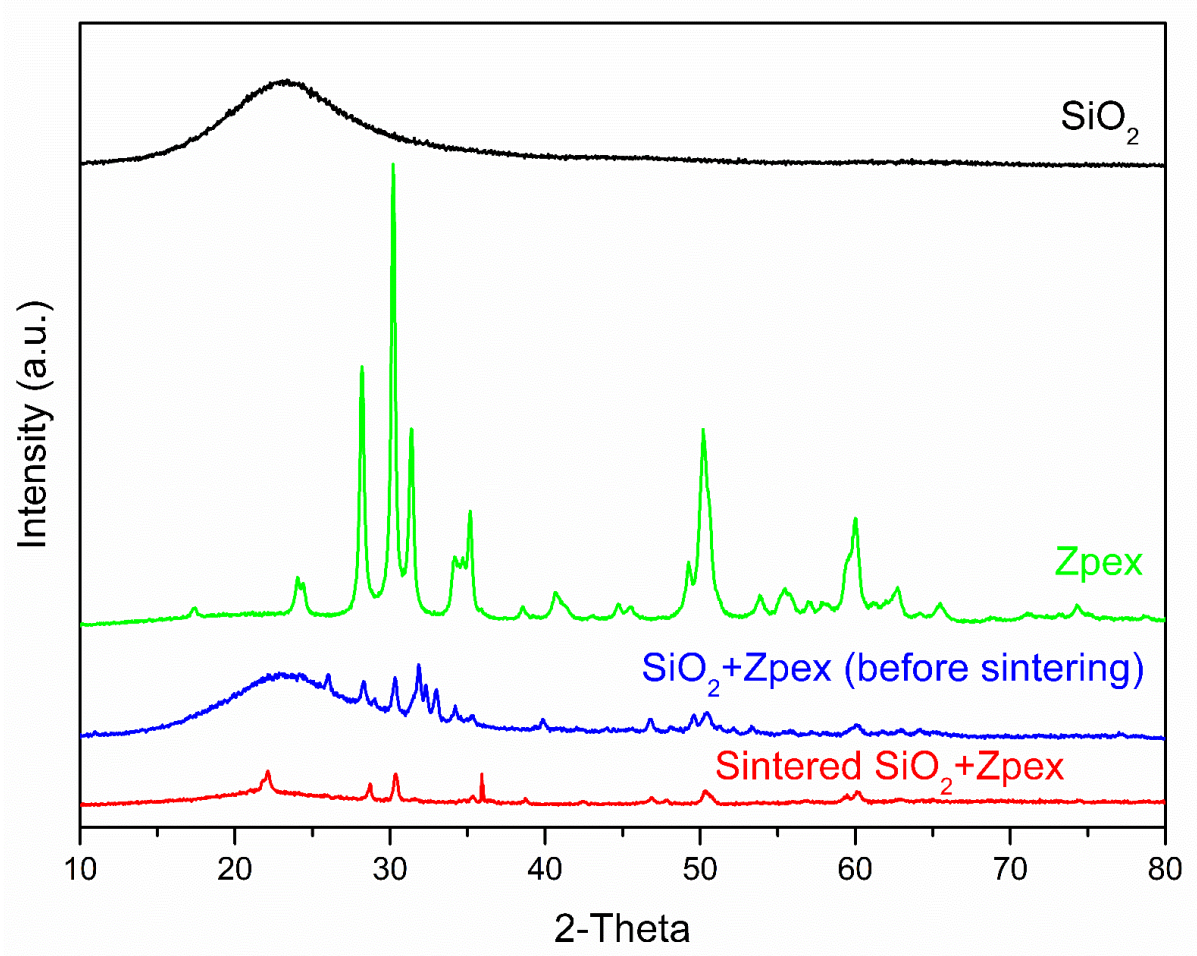

Figure 4: XRD patterns of the sample before and after sintering at $1150^{\circ} \mathrm{C}$ for $2 \mathrm{~h}$.

\section{4 - Fourier Transform Infrared Spectroscopy (FTIR)}

The silica powder and the Zpex powders were subjected to analysis by Fourier Transform Infrared Spectroscopy (FTIR) in order to detect the chemical interactions present in them. Three readings were performed in transmittance mode in each powder, where the band on the axis related to the wave number in $\mathrm{cm}^{-1}$ corresponds to a given chemical bond.

The assessment conducted on the silica powder indicated bands at 800 and $961 \mathrm{~cm}^{-1}$ assigned to $\mathrm{Si}-\mathrm{OH}$ groups and a band around $1000-1200 \mathrm{~cm}^{-1}$ attributed to the stretching vibration of Si-O-Si bonds (Figure 5). A delicate band at $1630 \mathrm{~cm}^{-1}$ was seen and related to adsorbed $\mathrm{H}_{2} \mathrm{O}$. Also, a band at $2300 \mathrm{~cm}^{-1}$ can be assigned to $\mathrm{CO}_{2}$.

When the Zpex was analyzed by FTIR, a broad band at the region of 550$650 \mathrm{~cm}^{-1}$ was seen, attributed to the $\mathrm{Zr}-\mathrm{O}$ bonds (Figure 5). Smaller bands located between $1000-1500 \mathrm{~cm}^{-1}$ can be assigned to different organic groups used in the manufacturing process of the Zpex powder. 
The physical mixture (before sintering) was also subjected to FTIR analysis. This analysis indicated the same bands at the region of $1000-1200 \mathrm{~cm}^{-1}, 961 \mathrm{~cm}^{-1}$ and $800 \mathrm{~cm}^{-1}$ attributed to bonds located in the silica powder, and bands in the $550-650 \mathrm{~cm}^{-}$ 1 region related to the Zpex powder. Also, the bands at $1630 \mathrm{~cm}^{-1}$ and $2300 \mathrm{~cm}^{-1}$ associated with adsorbed $\mathrm{H}_{2} \mathrm{O}$ and $\mathrm{CO}_{2}$, respectively. The $1100 \mathrm{~cm}^{-1}$ region is also related to the bond related to the interaction of $\mathrm{Si}$ and $\mathrm{Zr}$ ( $\mathrm{Si}-\mathrm{O}-\mathrm{Zr}$ bonds).

After sintering, the bands at $2300 \mathrm{~cm}^{-1}\left(\mathrm{CO}_{2}\right)$, and at $600-700 \mathrm{~cm}^{-1}(\mathrm{Zr}-\mathrm{O})$ were maintained. However, those bands located at $1000-12000 \mathrm{~cm}^{-1}$ (Si-O-Si), $961 \mathrm{~cm}^{-1}$ (Si$\mathrm{OH}$ ), were eliminated and that at $550 \mathrm{~cm}^{-1}$ lost intensity. The smaller bands located between $1000-1500 \mathrm{~cm}^{-1}$ were eliminated due to the temperature at which the specimens were subjected during sintering.

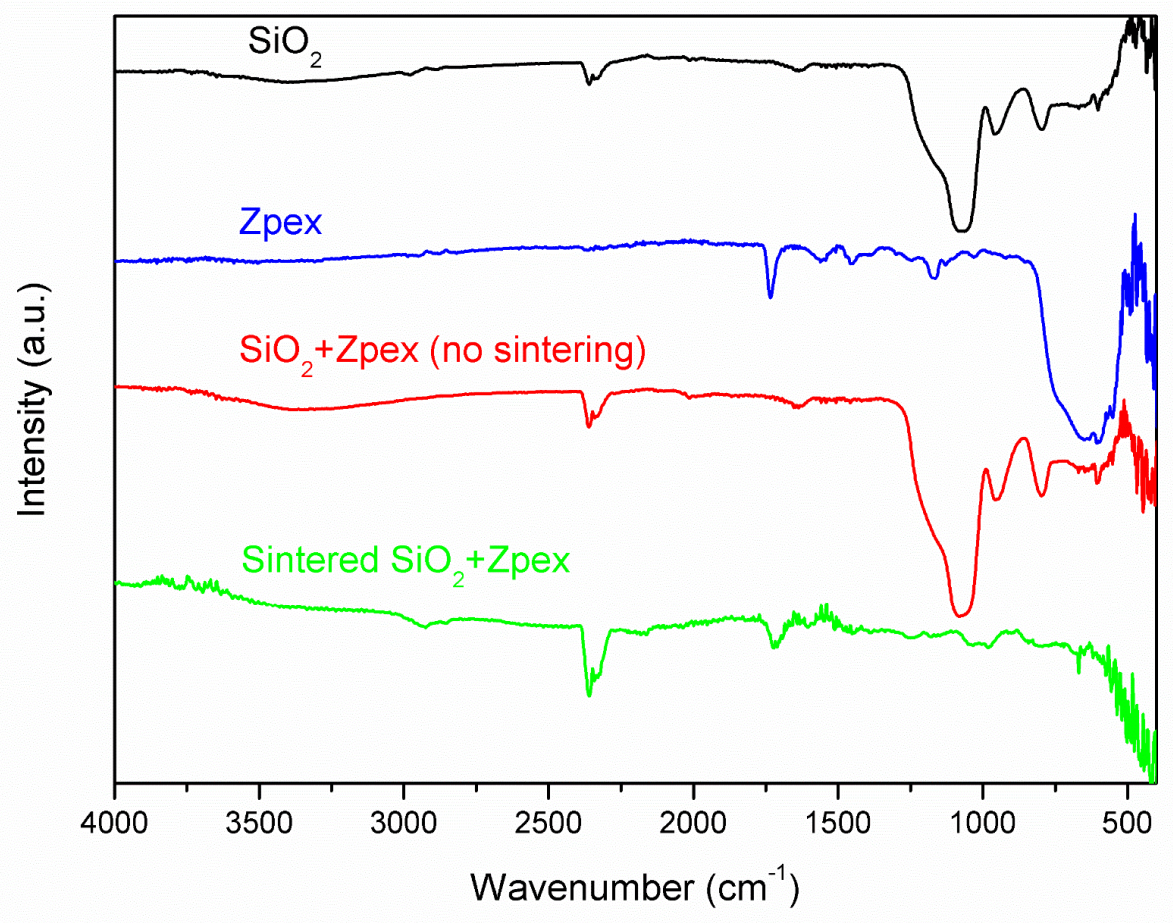

Figure 5: FTIR spectra of the sample before and after sintering at $1150^{\circ} \mathrm{C}$ for $2 \mathrm{~h}$.

\section{5 - THEORETICAL DENSITY TEST}

The theoretical density value of the experimental ceramics (silica+Zpex) was $1.663 \mathrm{~g} / \mathrm{cm}^{3}$. 


\section{6 - OPTICAL PROPERTIES}

\subsection{1 - Contrast ratio}

The contrast ratio (CR) measures the transparency or opacity of each material. The ESY group showed the highest CR value (more opaque), and it was significantly different from $C D$ and MAX groups ( $p=0,000001)$. The CD group showed the lowest CR value (less opaque), which was different from both MAX and ESY values. MAX showed an intermediate value of $C R$, and it differed from the values of CD and ESY (Table 2).

\subsection{2 - Translucency parameter}

The translucency parameter (TP) measures the masking capacity of each material. Lower $\Delta \mathrm{E}$ values indicate a better masking capacity. The ESY group showed the lowest $\triangle \mathrm{E}$ value (higher masking capacity), and it was different from both MAX and $C D$ values $(p=0,000001)$. The $C D$ group showed the highest $\Delta E$ value (lower masking capacity), and it was significantly different from MAX and ESY groups. MAX showed an intermediate value of $\triangle \mathrm{E}$, and it differed from the values of $C D$ and $E S Y$.

The medians of $\mathrm{CR}$ and $\Delta \mathrm{E}$ values are displayed in table 2, along with their first and third interquartile.

Table 2: $\mathrm{CR}$ and $\Delta \mathrm{E}$ values obtained after the statistical analysis.

\begin{tabular}{l|l|l}
\hline Group & Contrast Ratio & Translucency parameter $(\Delta \mathrm{E})$ \\
\hline ESZ & $0.999(0.996-1.000)^{\mathrm{A}}$ & $00.165(0.110-0.300)^{\mathrm{C}}$ \\
\hline MAX & $0.752(0.747-0.759)^{\mathrm{B}}$ & $11.485(11.225-11.650)^{\mathrm{B}}$ \\
\hline CD & $0.717(0,710-0.728)^{\mathrm{C}}$ & $13.350(12.778-13.795)^{\mathrm{A}}$ \\
\hline
\end{tabular}

*Different capital letters indicate difference between groups $(p=0.000001)$.

\section{Discussion}

This study was able to evidence an alternative method to obtain pure amorphous silica and also evidences an efficient method to synthesize a new glass ceramic containing $97 \%$ silica and $0.3 \%$ Zpex. The silica used in this study was considered pure, spherical and amorphous according to the data obtained by MEV/EDX, TEM and XDR analyses. Since its first use [23], the Stöber method has been widely used to produce silica by using the tetraethyl orthosilicate (TEOS) as a precursor $[11,24]$. Also, the size and shape of silica particles obtained in this study 
seem to be in accordance with the findings of Buckley and Greenblatt [25], where the use of ammonia as a catalyst (base catalyst) was able to form larger and more spherical particles/grain than when compared to the use of an acid as a catalyst [23]. These characteristics are important to control the translucency, homogeneity and even the deformation caused by sintering $[10,26]$ of the final experimental ceramic. Smaller primary particles could result in higher green-body strength and better densification, which can further improve the material's optical properties [10,27].

Similar to the silica powder, Zpex is also acquired by a hydrolysis method [28], according to the manufacturers. Other studies have been published using this method to produce zirconia-based materials [11,29-30], and depending on the precursors used in this process, it may justify the FTIR bands at around $1200-1600 \mathrm{~cm}^{-1}$, which may be attributed to organic compounds. These organic compounds are present in the spectra obtained when the Zpex powder was analyzed alone, and, due to the temperature at which this material was submitted, these bands were eliminated after sintering. On the other hand, despite the manufacturers stating that Zpex is commercialized in its tetragonal form, the XDR analysis evidenced that monoclinic zirconia is also present in the powder.

After mixing silica and Zpex, a reduction in intensity of the Zpex peaks was seen in the XRD patterns. This may be attributed to the proportion of silica/Zpex used to prepare the ceramic material. Also, when these two initial powders were mixed and analyzed under TEM, it is possible to observe that the nano-sized $\mathrm{ZrO}_{2}$ was surrounded by $\mathrm{SiO}_{2}$ grains. This could also indicate the formation of a $\mathrm{Zr}-\mathrm{O}-\mathrm{Si}$ interlayer, as evidenced by Persson et al. [11]. This interaction between $\mathrm{Zr}$, O and $\mathrm{Si}$ would be shown in the FTIR spectra close the $1100 \mathrm{~cm}^{-1}$ region regarded as the asymmetric stretching vibration of this bond [31], yet, due to the intensity of Si-O-Si bonds, seen closely to the same region, this band may not be properly evident.

During mixing, PVB was used as a binding agent in this study. Some studies have also evidenced that the use of a binder may lead to the formation of porosities if not properly eliminated, leading to reduced translucency and mechanical properties after sintering [10, 27]. However, in ambient conditions, the silicon surface is readily covered by oxygen, due to their strong affinity. This makes it difficult to deform these elements and compact then by using a uniaxial/isostatic press without resorting to a binding agent to provide green-body strength [32]. Without a binding agent, the greenbody strength of this study's experimental ceramic would rely solely on the van der 
Waals attraction forces, and could make the compacted specimen susceptible to damage during its removal from the die and handling [27,32].

The mixture containing silica, Zpex and a binding agent was submitted to uniaxial/isostatic powder compressing. This technique has been used to create highly dense and mechanically resistant alternative ceramic materials [9-10,33]. In this study, the experimental ceramic presented lower translucency than IPS e.max® CAD and Celtra Duo®. This finding is in accordance with the study of Mouzon et al. [9], in which the specimens obtained by the uniaxial/isostatic powder compressing technique presented lower translucency when compared to the slip-casting technique.

After compressing this powder, the green-body specimens were sintered at $1150^{\circ} \mathrm{C}$ for $2 \mathrm{~h}$ in this study. During the sintering stages, at $600-700^{\circ} \mathrm{C}$ the binder is burned out [34]. The increase in the intensity of the FTIR band seen at $2300 \mathrm{~cm}^{-1}$ could be attributed to the imprisonment of $\mathrm{CO}_{2}$ [35] inside the bulk of the material attributed to the evaporation of the binding agent.

Other studies have shown that silica can be compacted at temperatures close to $1250^{\circ} \mathrm{C}-1300^{\circ} \mathrm{C}[32,36]$. However, previous studies evidenced that a tetragonalmonoclinic metastable transformation can be seen if zirconia is submitted to temperatures between $1150^{\circ} \mathrm{C}-1200^{\circ} \mathrm{C}[11,37]$. These studies contrast with the findings to this study, once the $1150^{\circ} \mathrm{C}$ temperature did not induce the $t-m$ phase transformation in zirconia under XDR analysis. Yet, under SEM assessment, it can be seen that the spherical character of silica particles was maintained. This maintenance in the particles shape could also indicate that higher temperature and/or longer periods should be used to promote a better densification of the experimental material.

Despite the maintenance of the silica shape, the XRD patterns evidence that this temperature was sufficient to crystallize the amorphous silica particles. Yet, $2 \mathrm{~h}$ seem to be insufficient to promote crystal growth, once the intensity of the XDR peak attributed to silica crystallization is quite mild. These findings corroborate to the study of Persson et al. [11], in which $\mathrm{SiO}_{2}-\mathrm{ZrO}_{2}$ ceramics were submitted to either 10 or 15hour sintering stages, and it resulted in more intense silica XRD peaks, in spite of the percentage of silica being smaller than in this study.

Nonetheless, in the study conducted by Jiang et al. [10], Y-TZP specimens were sintered for $2 \mathrm{~h}$ and translucency was achieved even for primary particles over $40 \mathrm{~nm}$. It points out that primary particles size and temperature of sintering are important factors to be taken into account in order to achieve proper translucency [10]. In this 
study, however, the temperature used is lower than in Jiang's study, which could be held responsible for the lower densification and, consequently, lower translucency obtained for the experimental ceramic. Residual pores play an important role at the amount of light that is absorbed, reflected, and transmitted through the material $[10,15,38]$ due to different refractive indices, making this material look opaque.

In view of what has been discussed, the use of a binding agent associated with short sintering period and lower temperatures could have resulted in a high level of porosities, which hindered the translucency of the experimental material. Yet, it is important to highlight that this study contributes to the scientific literature by evidencing that the uniaxial/isostatic powder compression is an efficient processing method of experimental ceramics with dental purposes.

Further studies are necessary to investigate if different sintering protocols are sufficient to eliminate the pores of this material even in the presence of a binding agent and promote crystal growth and better translucency. Also, if these higher temperatures are tested, the $t-m$ metastable transformation should also be analyzed, associated with mechanical tests in order to properly evaluate the sintering consequences in the material's physical and mechanical properties in order for it to be used as an alternative dental ceramic.

\section{Conclusion}

Within the limitations of this study, it can be concluded that the uniaxial/isostatic powder compression is an efficient method to obtain experimental ceramics for dental purposes. Also, $1150^{\circ} \mathrm{C}$ for $2 \mathrm{~h}$ is sufficient to crystallize $\mathrm{SiO} 2$ without inducing $\mathrm{t}-\mathrm{m}$ transformation of zirconia. Yet, this sintering protocol seems to be insufficient to densify the experimental ceramic, which consequently resulted in higher contrast ratio and lower translucency parameter when compared to lithium disilicate and zirconiareinforced lithium silicate. Further studies with different sintering protocols are needed in order to properly achieve a good balance between optical and mechanical properties for this experimental material.

\section{Acknowledgements}

This study was financed by São Paulo Research Foundation (FAPESP, \#2017/18157-4). This study was financed in part by the Coordenação de Aperfeiçoamento de Pessoal de Nível Superior - Brasil (CAPES) - Finance Code 001. 


\section{References}

[1] J. R. Kelly, P. Benetti, Ceramic materials in dentistry: historical evolution and current practice, Aust. Dent. J. 56 (2011) 84-96.

[2] A. P. Amoroso, M. B. Ferreira, L. B. Torcato, E. P. Pellizzer, J. V. Q. Mazaro, H. Gennari Filho, Dental ceramics: properties, indications and clinical considerations. Rev. Odontol. Araç. 33 (2012) 19-25.

[3] J. R. Kelly, Dental ceramics: what is this stuff anyway?, J. Am. Dent. Assoc. 139 (2008) 4S-7S.

[4] J. Chavalier, L. Gremillard, S. Deville, Low-temperature degradation of zirconia and implications for biomedical implants, Annu. Rev. Mater. Res. 37 (2007) 1-32.

[5] J. R. Kelly, I. Denry, Stabilized zirconia as a structural ceramic: an overview, Dent. Mater. 24 (2008) 289-298.

[6] O. S. A. El-Gahny, A. H. SHERIEF, Zirconia based ceramics, some clinical and biological aspects: review, Future Dent. J. 2 (2016) 55-64.

[7] M. Guazzato, M. Albakry, S. P. Ringer, M. V. Swain, Strength, fracture toughness and microstructure of a selection of all-ceramic materials. Part II. Zirconia-based dental ceramics, Dent. Mater. 20 (2004) 449-456.

[8] C. M. RAMOS, A. S. Tabata, P. F. Cesar, J. H. Rubo, P. A. Fracisconi, A. F. Sanches Borges, Application of micro-raman spectroscopy to the study of yttriastabilized tetragonal zirconia polycrystal (Y-TZP) phase transformation, Appl. Spectrosc. 69 (2015) 810-814.

[9] J. Mouzon, E. Glowacki, M. Odén, Comparison between slip-casting and uniaxial pressing for the fabrication of translucent yttria ceramics, J. Mater. Sci. 43 (2008) 2849-2856.

[10] L. Jiang, Y. Liao, Q. Wan, W. Li, Effects of sintering temperature and particle size on the translucency of zirconium dioxide dental ceramic, J. Mater. Sci: Mater. Med. 22 (2011) 2429-2435.

[11] C. Persson, E. Unosson, I. Ajaxon, J. Engstrand, H. Engqvist, W. Xia, Nano grain sized zirconia-silica glass ceramics for dental applications, J. Eur. Ceram. Soc. 32 (2012) 4105-4110.

[12] C. A. M. Volpato, L. G. D. Garbelotto, M. C. Fredel, F. Bondioli, Application of zirconia in dentistry: biological, mechanical and optical considerations. In: C. 
SIKALIDIS, Advances in ceramics: electric and magnetic ceramics, bioceramics, ceramics and environment, 2011, pp. 397-420.

[13] J. F. McCabe, A. W. G. Walls, Ceramics and porcelain fused to metal (PFM). In: J. F. McCabe, A. W. G. Walls, Applied dental materials. Oxford, 2008, pp. 89-100.

[14] R. H. W. Brodbelt, W. J. O'Brien, P. L. Fan, Translucency of dental porcelains. J. Dent. Res. 59 (1980) 70-75.

[15] M. J. Heffernan, S. A. Aquilino, A. M. Diaz-Arnold, D. R. Haselton, C. M. Stanford, M. A. Vargas, Relative translucency of six all-ceramic systems. Part I: Core materials, J. Prosthet. Dent. 88 (2002) 4-9.

[16] A. D. Nogueira, A. Della Bona, The effect of a coupling medium on color and translucency of CAD-CAM ceramics. J. Dent. 41 (2013) e18-23.

[17] D. M. dos Santos, E. V. F. da Silva, D. Watanabe, S. B. Bitencourt, A. M. Guiotti, M. C. Goiato, Effect of different acidic solutions on the optical behavior of lithium disilicate ceramics, J. Prosthet. Dent. 118 (2017) 430-436.

[18] A. Della Bona, A. D. Nogueira, O. E. Pecho, Optical properties of CAD-CAM ceramic systems, J. Dent. 42 (2014) 1202-1209.

[19] F. C. Chu, T. W. Chow, J. Chai, Contrast ratios and masking ability of three types of ceramic veneers, J. Prosthet. Dent. 98 (2007) 359-364.

[20] J. D. Hanawalt, H. W. Rinn, L. K. Frevel, Chemical analysis by X-Ray diffraction, Indust. Chem. Anal. Ed. 10 (1938) 475-512.

[21] O. Ruff, F. Ebert, E. Stephan, Beitrage zur keramik hochfeurfe stoffe II. Das system ZrO2-CaO, Z. Anorg. Allg. Chem. 180 (1929) 215-224.

[22] R. W. G. Wyckoff, Crystal structure of high temperature cristobalite, Am. J. Sci. 9 (1925) 448-459.

[23] W. Stöber, A. Fink, E. Bohn, Controlled growth of monodisperse silica spheres in the micron size range, J. Colloid. Interface. Sci. 26 (1968) 62-69.

[24] U. K. H. Bangi, C. Park, S. Baek, H. Park, Improvement in optical and physical properties of TEOS based aerogels using acetonitrile via ambient pressure drying, Ceram. Int. 38(2012) 6883-6888.

[25] A. M. Buckley, M. Greenblatt, The sol-gel preparation of silica gels, J. Chem. Educ. 71 (1994) 599-602. 
[26] A. SHUI, Z. Kato, S. Tanaka, N. Uchida, K. Uematsu, Sintering deformation caused by particle orientation in uniaxially and isostatically pressed alumina compacts, J. Eur. Ceram. Soc. 22 (2002) 311-316.

[27] P. Pizette, C. L. Martin, G. Delette, F. Sans, T. Geneves, Green strength of binderfree ceramics, J. Eur. Ceram. Soc. 33 (2013) 975-984.

[28] TOSOH. Advanced Ceramics | Zirconia Powders. https://www.tosoh.com/ourproducts/advanced-materials/zirconia-powders (accessed 29 march 2019).

[29] D. S. S. Padovini, D. S. L. Pontes, C. J. Dalmaschio, F. M. Pontes, E. Longo, Facile synthesis and characterization of $\mathrm{ZrO} 2$ nanoparticles prepared by the AOP/hydrothermal route, RSC. Adv. 4(2014) 38484-38490.

[30] E. W. Leib, U. Vainio, R. M. Pasquarelli, J. Kus, C. Czaschke, N. Walter, R. Janssen, M. Müller, A. Schreyer, H. Weller, T. Vossmeyer, Synthesis and thermal stability of zirconia and yttria-stabilized zirconia microspheres, J. Colloid. Interface. Sci. 448 (2015) 582-592.

[31] PADOVINI, D. S. S. Estudo de adsorção e fotodegradação da rodamina $b \mathrm{com}$ nanopartículas core-shell de $\mathrm{ZrO}_{2} @ \mathrm{SiO}_{2}$ preparadas pelo método sol-gel. 2018. Dissertation (Master in Materials Science) - School of Science, University of the State of São Paulo-UNESP, São Paulo.

[32] K. G. Barraclough, A. Loni, E. Caffull, L. T. Canham, Cold compaction of silicon powders without a binding agent, Mater. Lett. 61 (2007) 485-487.

[33] A. C. O. Lopes, P. G. Coelho, L. Witek, E. B. Benalcázar Jalkh, L. A. Gênova, K. N. Monteiro, P. F. Cesar, P. N. Lisboa Filho, E. T. P. Bergamo, I. S. Ramalho, E. A. Bonfante, Nanomechanical and microstructural characterization of a zirconiatoughened alumina composite after aging. Ceram Int. [in press].

[34] S. Baklouti, J. Bouaziz, T. Chartier, J. Baumard, Binder burnout and evolution of the mechanical strength of dry-pressed ceramics containing poly(vinyl acohol), J. Eur. Ceram. Soc. 21 (2001) 1087-1092.

[35] M. Sanati, A. Andersson, DRIFT study of the oxidation and the ammoxidation of toluene over a $\mathrm{TiO}_{2}$ (B) -supported vanadia catalyst, J. Mol. Catal. 81 (1993) 5162.

[36] C. J. Santana, K. S. Jones, The effects of processing conditions on the density and microstructure of hot-pressed silicon powder, J. Mater. Sci. 31 (1996) 4985-4990. 
[37] M. Nogami, M. Tomozawa, $\mathrm{ZrO}_{2}$-transformation-toughened glass-ceramics prepared by the sol-gel process from metal alkoxides, J. Am. Ceram. Soc. 69 (1986) 99-102.

[38] J. G. J. Peelen, R. Metselaar, Light scattering by pores in poly-crystalline materials, J. Appl. Phys. 45 (1974) 216-220. 
3 DISCUSSION 



\section{DISCUSSION}

This study was able to evidence an alternative method to obtain pure amorphous silica and also evidences an efficient method to synthesize a new glass ceramic containing $97 \%$ silica and $0.3 \%$ Zpex. The silica used in this study was considered pure, spherical and amorphous according to the data obtained by MEV/EDX, TEM and XDR analyses. Since its first use (STÖBER, FINK, BOHN, 1968), the Stöber method has been widely used to produce silica by using the tetraethyl orthosilicate (TEOS) as a precursor (PERSSON et al., 2012; BANGI et al., 2012).

The modified Stöber method (STÖBER, FINK, BOHN, 1968) uses tetraethyl orthosilicate (TEOS) as a precursor. TEOS, also known as tetraethoxysilane, counts with 4 ethyl groups. Hydrolysis occurs upon the addition of water, and a hydrogen ion is attached to the oxygen ion, resulting in $\mathrm{Si}-\mathrm{OH}$. The addition of ammonium hydroxide $\left(\mathrm{NH}_{4} \mathrm{OH}\right)$ promotes condensation and the $\mathrm{H}$ ion detaches from the $\mathrm{Si}-\mathrm{OH}$ bond. This allows the $\mathrm{Si}-\mathrm{O}$ bonds to react with other $\mathrm{Si}-\mathrm{O}$ bonds, leading to the formation of silica. Thereafter, due to the temperature at which the beaker is maintained, the $\mathrm{NH}_{4} \mathrm{OH}$ is evaporated, as well as the remaining alcohol. In this study, the purity of this powder could be confirmed under EDX analysis, yet, under SEM, the particles size could not be precisely calculated, since only agglomerations could be seen.

Also, the size and shape of silica particles obtained in this study seem to be in accordance with the findings of Buckley and Greenblatt (1994), where the use of ammonia as a catalyst (base catalyst) was able to form larger and more spherical particles/grain than when compared to the use of an acid as a catalyst (STÖBER, FINK, BOHN, 1968). These characteristics are important to control the translucency, homogeneity and even the deformation caused by sintering (SHUI et al., 2002; JIANG et al., 2011) of the final experimental ceramic. Smaller primary particles could result in higher green-body strength and better densification, which can further improve the material's optical properties (JIANG et al., 2011; PIZETTE et al., 2013).

Similar to the silica powder, Zpex is also acquired by a hydrolysis method (TOSOH, 2019), according to the manufacturers. Other studies have been published using this method to produce zirconia-based materials (PERSSON et al., 2012; PADOVINI et al., 2014; LEIB et al., 2015,), and depending on the precursors used in 
this process, it may justify the FTIR bands at around $1200-1600 \mathrm{~cm}^{-1}$, which may be attributed to organic compounds. These organic compounds are present in the spectra obtained when the Zpex powder was analyzed alone, and, due to the temperature at which this material was submitted, these bands were eliminated after sintering. On the other hand, despite the manufacturers stating that Zpex is commercialized in its tetragonal form, the XDR analysis evidenced that monoclinic zirconia is also present in the powder.

After mixing silica and Zpex, a reduction in intensity of the Zpex peaks was seen in the XRD patterns. This may be attributed to the proportion of silica/Zpex used to prepare the ceramic material. Also, when these two initial powders were mixed and analyzed under TEM, it is possible to observe that the nano-sized $\mathrm{ZrO}_{2}$ was surrounded by $\mathrm{SiO}_{2}$ grains. This could also indicate the formation of a $\mathrm{Zr}$-O-Si interlayer, as evidenced by Persson et al. (2012). This interaction between Zr, O and Si would be shown in the FTIR spectra close the $1100 \mathrm{~cm}^{-1}$ region regarded as the asymmetric stretching vibration of this bond (PADOVINI, 2018), yet, due to the intensity of Si-O-Si bonds, seen closely to the same region, this band may not be properly evident.

During mixing, PVB was used as a binding agent in this study. Some studies have also evidenced that the use of a binder may lead to the formation of porosities if not properly eliminated, leading to reduced translucency and mechanical properties after sintering (JIANG et al., 2011; PIZETTE et al., 2013). However, in ambient conditions, the silicon surface is readily covered by oxygen, due to their strong affinity. This makes it difficult to deform these elements and compact then by using a uniaxial/isostatic press without resorting to a binding agent to provide green-body strength (BARRACLOUGH et al., 2007). Without a binding agent, the green-body strength of this study's experimental ceramic would rely solely on the van der Waals attraction forces, and could make the compacted specimen susceptible to damage during its removal from the die and handling (BARRACLOUGH et al., 2007; PIZETTE et al., 2013).

The mixture containing silica, Zpex and a binding agent was submitted to uniaxial/isostatic powder compressing. This technique has been used to create highly dense and mechanically resistant alternative ceramic materials (MOUZON, GLOWACKI, ODÉN, 2008; JIANG et al., 2011; LOPES et al., 2019). In this study, the experimental ceramic presented lower translucency than IPS e.max® CAD and Celtra 
Duo®. This finding is in accordance with the study of Mouzon et al. (2008), in which the specimens obtained by the uniaxial/isostatic powder compressing technique presented lower translucency when compared to the slip-casting technique.

After compressing this powder, the green-body specimens were sintered at $1150^{\circ} \mathrm{C}$ for $2 \mathrm{~h}$ in this study. During the sintering stages, at $600-700^{\circ} \mathrm{C}$ the binder is burned out (BAKLOUTI et al., 2001). The increase in the intensity of the FTIR band seen at $2300 \mathrm{~cm}^{-1}$ could be attributed to the imprisonment of $\mathrm{CO}_{2}$ (SANATI, ANDERSSON ,1993) inside the bulk of the material attributed to the evaporation of the binding agent.

Other studies have shown that silica can be compacted at temperatures close to $1250^{\circ} \mathrm{C}-1300^{\circ} \mathrm{C}$ (SANTANA, JONES, 1996; BARRACLOUGH et al., 2007). However, previous studies evidenced that a tetragonal-monoclinic metastable transformation can be seen if zirconia is submitted to temperatures between $1150^{\circ} \mathrm{C}$ $1200^{\circ} \mathrm{C}$ (NOGAMI, TOMOZAWA, 1986; PERSSON et al., 2013). These studies contrast with the findings to this study, once the $1150^{\circ} \mathrm{C}$ temperature did not induce the $t-m$ phase transformation in zirconia under XDR analysis. Yet, under SEM assessment, it can be seen that the spherical character of silica particles was maintained. This maintenance in the particles shape could also indicate that higher temperature and/or longer periods should be used to promote a better densification of the experimental material.

Despite the maintenance of the silica shape, the XRD patterns evidence that this temperature was sufficient to crystallize the amorphous silica particles. Yet, $2 \mathrm{~h}$ seem to be insufficient to promote crystal growth, once the intensity of the XDR peak attributed to silica crystallization is quite mild. These findings corroborate to the study of Persson et al. (2012) in which $\mathrm{SiO}_{2}-\mathrm{ZrO}_{2}$ ceramics were submitted to either 10 or 15-hour sintering stages, and it resulted in more intense silica XRD peaks, in spite of the percentage of silica being smaller than in this study.

Nonetheless, in the study conducted by Jiang et al. (2011), Y-TZP specimens were sintered for $2 \mathrm{~h}$ and translucency was achieved even for primary particles over $40 \mathrm{~nm}$. It points out that primary particles size and temperature of sintering are important factors to be taken into account in order to achieve proper translucency (JIANG et al., 2011). In this study, however, the temperature used is lower than in Jiang's study, which could be held responsible for the lower densification and, consequently, lower translucency obtained for the experimental ceramic. Residual 
pores play an important role at the amount of light that is absorbed, reflected, and transmitted through the material (PEELEN, METSELAAR, 1974; HEFFERNAN et al., 2002; JIANG et al., 2011) due to different refractive indices, making this material look opaque.

In view of what has been discussed, the use of a binding agent associated with short sintering period and lower temperatures could have resulted in a high level of porosities, which hindered the translucency of the experimental material. Yet, it is important to highlight that this study contributes to the scientific literature by evidencing that the uniaxial/isostatic powder compression is an efficient processing method of experimental ceramics with dental purposes.

Further studies are necessary to investigate if different sintering protocols are sufficient to eliminate the pores of this material even in the presence of a binding agent and promote crystal growth and better translucency. Also, if these higher temperatures are tested, the $t-m$ metastable transformation should also be analyzed, associated with mechanical tests in order to properly evaluate the sintering consequences in the material's physical and mechanical properties in order for it to be used as an alternative dental ceramic. 
4 FINAL CONSIDERATIONS 



\section{FINAL CONSIDERATIONS}

Within the limitations of this study, it can be concluded that the uniaxial/isostatic powder compression is an efficient method to obtain experimental ceramics for dental purposes. Also, $1150^{\circ} \mathrm{C}$ for $2 \mathrm{~h}$ is sufficient to crystallize $\mathrm{SiO}_{2}$ without inducing $\mathrm{t}-\mathrm{m}$ transformation of zirconia. Yet, this sintering protocol seems to be insufficient to densify the experimental ceramic, which consequently resulted in higher contrast ratio and lower translucency parameter when compared to lithium disilicate and zirconiareinforced lithium silicate. Further studies with different sintering protocols are needed in order to properly achieve a good balance between optical and mechanical properties for this experimental material. 

REFERENCES 



\section{REFERENCES}

AMOROSO, A. P. et al. Dental ceramics: properties, indications and clinical considerations. Rev Odontol Araç, v. 33, n. 2, p. 19-25, Jul-Dec 2012.

BAKLOUTI, S. et al. Binder burnout and evolution of the mechanical strength of drypressed ceramics containing poly(vinyl acohol). J Eur Ceram Soc, v. 21, p. 10871092, 2001.

BANGI, U. K. H. et al. Improvement in optical and physical properties of TEOS based aerogels using acetonitrile via ambient pressure drying. Ceram Int, v. 38, p. 68836888, 2012.

BARRACLOUGH, K. G. et al. Cold compaction of silicon powders without a binding agent. Mater Lett, v. 61, p. 485-487, 2007.

BRODBELT, R. H. W.; O'BRIEN, W. J.; FAN, P. L. Translucency of dental porcelains. J Dent Res, v. 59, n. 1, p. 70-75, Jan 1980.

BUCKLEY, A. M.; GREENBLATT, M. The sol-gel preparation of silica gels. J Chem Educ, v. 71, n. 7, p. 599-602, Jul 1994.

CHAVALIER, J.; GREMILLARD, L.; DEVILLE, S. Low-temperature degradation of zirconia and implications for biomedical implants. Annu Rev Mater Res, v. 37, p. 132, Apr 2007.

CHU, F. C; CHOW, T. W.; CHAI, J. Contrast ratios and masking ability of three types of ceramic veneers. J Prosthet Dent, v. 98, n. 5, p. 359-364, Nov 2007.

DELLA BONA, A.; NOGUEIRA, A. D.; PECHO, O. E. Optical properties of CAD-CAM ceramic systems. J Dent, v. 42, n. 9, p. 1202-1209, Sept 2014.

DOS SANTOS, D. M. et al. Effect of different acidic solutions on the optical behavior of lithium disilicate ceramics. J Prosthet Dent, v. 118, n.3, p.430-436, Sept 2017.

EL-GAHNY, O. S. A.; SHERIEF, A. H. Zirconia based ceramics, some clinical and biological aspects: review. Future Dent J, v. 2, n. 2, p. 55-64, Oct 2016. 
GUAZZATO, M. et al. Strength, fracture toughness and microstructure of a selection of all-ceramic materials. Part II. Zirconia-based dental ceramics. Dent Mater, v. 20, n. 5, p. 449-456, Jun 2004.

HANAWALT, J. D.; RINN, H. W.; FREVEL, L. K. Chemical analysis by X-Ray diffraction. Indust Chem Anal Ed, v. 10, p. 475-512, 1938.

HEFFERNAN, M. J. et al. Relative translucency of six all-ceramic systems. Part I: Core materials. J Prosthet Dent, v. 88, n. 1, p. 4-9, 2002.

JIANG, L. et al. Effects of sintering temperature and particle size on the translucency of zirconium dioxide dental ceramic. J Mater Sci: Mater Med, v. 22, p. 2429-2435, 2011.

KELLY, J. R. Dental ceramics: what is this stuff anyway? J Am Dent Assoc, v. 139, p. 4S-7S, Sept 2008.

KELLY, J. R.; BENETTI, P. Ceramic materials in dentistry: historical evolution and current practice. Aust Dent J, v. 56, n. 1, p. 84-96, Jun 2011.

KELLY, J. R.; DENRY, I. Stabilized zirconia as a structural ceramic: an overview. Dent Mater, v. 24, n. 3, p. 289-298, Mar 2008.

LEIB, E. W. et al. Synthesis and thermal stability of zirconia and yttria-stabilized zirconia microspheres. J Colloid Interface Sci, v. 448, p. 582-592, Jun 2015.

LOPES, A. C. O. et al. Nanomechanical and microstructural characterization of a zirconia-toughened alumina composite after aging. Ceram Int. [in press].

MCCABE, J. F.; WALLS, A. W. G. Ceramics and porcelain fused to metal (PFM). In: Applied dental materials. 9th Ed. Oxford: Blackwell Publishing Ltda, 2008. cap 11, p. 89-100.

MOUZON, J.; GLOWACKI, E.; ODÉN, M. Comparison between slip-casting and uniaxial pressing for the fabrication of translucent yttria ceramics. J Mater Sci, v. 43, p. 2849-2856, 2008.

NOGAMI, M.; TOMOZAWA, M. ZrO2-transformation-toughened glass-ceramics prepared by the sol-gel process from metal alkoxides. J Am Ceram Soc, v. 69, n. 2, p. 99-102, 1986. 
NOGUEIRA, A. D; DELLA BONA, A. The effect of a coupling medium on color and translucency of CAD-CAM ceramics. J Dent, v. 41, n. 3, p. e18-23, Aug 2013.

PADOVINI, D. S. S. et al. Facile synthesis and characterization of $\mathrm{ZrO} 2$ nanoparticles prepared by the AOP/hydrothermal route. RSC Adv, v. 4, p. 38484-38490, 2014.

PADOVINI, D. S. S. Estudo de adsorção e fotodegradação da rodamina $b$ com nanopartículas core-shell de $\mathrm{ZrO}_{2} @ \mathrm{SiO}_{2}$ preparadas pelo método sol-gel. 2018. Dissertation (Master in Materials Science) - School of Science, University of the State of São Paulo-UNESP, São Paulo.

PEELEN, J. G. J.; METSELAAR, R., Light scattering by pores in poly-crystalline materials. J Appl Phys, v. 45, n. 1, p. 216-220, 1974.

PERSSON et al. Nano grain sized zirconia-silica glass ceramics for dental applications. J Eur Ceram Soc, v. 32, p. 4105-4110, 2012.

PIZETTE, P. et al. Green strength of binder-free ceramics. J Eur Ceram Soc, v. 33, p. 975-984, 2013.

RAMOS, C. M. et al. Application of micro-raman spectroscopy to the study of yttriastabilized tetragonal zirconia polycrystal (Y-TZP) phase transformation. Appl Spectrosc, v. 69, n. 7, p. 810-814, Jul 2015.

RUFF, O; EBERT, F.; STEPHAN, E. Beitrage zur keramik hochfeurfe stoffe II. Das system ZrO2-CaO. Z Anorg Allg Chem, v 180, n. 1, p. 215-224, 1929.

SANATI, M.; ANDERSSON, A. DRIFT study of the oxidation and the ammoxidation of toluene over a $\mathrm{TiO}_{2}$ (B) -supported vanadia catalyst. J Mol Catal, v. 81, p. 51-62, 1993.

SANTANA, C. J.; JONES, K. S. The effects of processing conditions on the density and microstructure of hot-pressed silicon powder. J Mater Sci, v. 31, p. 4985-4990, 1996.

SHUI, A. et al. Sintering deformation caused by particle orientation in uniaxially and isostatically pressed alumina compacts. J Eur Ceram Soc, v. 22, p. 311-316, 2002.

STÖBER, W.; FINK, A.; BOHN, E. Controlled growth of monodisperse silica spheres in the micron size range. J Colloid Interface Sci, v. 26, p. 62-69, 1968. 
TOSOH. Advanced Ceramics | Zirconia Powders. Available at: $<$ https://www.tosoh.com/our-products/advanced-materials/zirconia-powders>. Access on: March 29th 2019.

VOLPATO, C. A. M. et al. Application of zirconia in dentistry: biological, mechanical and optical considerations. In: SIKALIDIS, C. Advances in ceramics: electric and magnetic ceramics, bioceramics, ceramics and environment. 1st Ed. Rijeka: InTech, 2011. cap 17. p. 397-420.

WYCKOFF, R. W. G. Crystal structure of high temperature cristobalite. Am J Sci, v. 9, n. 5, p. 448-459, Jun 1925. 